\title{
GOT1 wt Allele
}

National Cancer Institute

\section{Source}

National Cancer Institute. GOT1 wt Allele. NCI Thesaurus. Code C51019.

Human GOT 1 wild-type allele is located within 10q24.1-q25.1 and is approximately $34 \mathrm{~kb}$ in length. This allele, which encodes aspartate aminotransferase, cytoplasmic protein, is involved in the reversible transamination between L-aspartate and 2-oxoglutarate to form oxaloacetate and L-glutamate. 